\title{
Kırıkkale yöresinde üretilen bazı kaba yemlerde besin madde miktarları ve metabolize olabilir enerji düzeylerinin belirlenmesi
}

\author{
Tülin GÜNGÖR, Mehmet BAŞALAN, İkay AYDOĞAN
}

Kırıkkale Üniversitesi Veteriner Fakültesi Hayvan Besleme ve Beslenme Hastalıkları Anabilim Dalı, Kırıkkale.

\begin{abstract}
Özet: Bu çalışma Kırıkkale yöresinde üretilen ve ruminant beslemede yaygın olarak kullanılan bazı kaba yemlerde ham besin madde miktarları ile metabolize olabilir enerji (ME) düzeylerinin belirlenmesi amacıyla yapılmıştır. Araştırmada Kırıkkale yöresinde üretilen bazı kaba yemler (yonca kuru otu, macar fiği kuru otu, mısır silajı, kuru mısır hasılı, buğday samanı, nohut samanı ve üzüm cibresi) kullanılmıştır. Kaba yem örneklerinde kuru madde (KM), ham protein (HP), ham kül (HK), ham yağ (HY) analizleri Weende analiz sistemine göre ve ham selüloz (HS) analizleri ise Crampton ve Maynard metoduna göre yapılmıştır. Yemlerin asit deterjan fiber (ADF) ve asit deterjan lignin (ADL) içerikleri ise Van Soest yöntemine göre belirlenmiştir. Yem maddelerinde ME değerleri HS, ADF ve ADL sonuçlarından yararlanılarak hesaplanmıştır. Kaba yemlerin KM düzeyleri \%90.12-95.31 arasında değişmektedir. İyi kaliteli ve kötü kaliteli yonca kuru otu, mısır silajı, buğday samanı ve üzüm cibresinde ortalama HP ve HS miktarları sırasıyla \%20.26, 12.11, 5.61, 3.63, 12.15 ve 24.71, 30.62, 33.30, 45.53, 33.52 olarak belirlenmiştir. Bu çalışmada, Kırıkkale yöresinde üretilen bazı kaba yemlerin besin madde kompozisyonu ve enerji değerleri tespit edilerek tablo haline getirilmiştir.

Anahtar sözcükler: Besin maddesi, kaba yem, metabolize olabilir enerji.
\end{abstract}

\section{The determination of nutrient contents and metabolizable energy levels of some roughages produced in Kirikkale region}

Summary: This experiment was carried out to determine the nutrient contents and metabolizable energy (ME) levels of some roughages produced in Kirikkale region. Alfalfa hay, hungarian vetch hay, corn silage, dried crop corn, wheat straw, chickpea straw and grape pomace were used in this experiment. In this study the levels of dry matter (DM), crude protein (CP), ether extracts (EE) and crude ash (CA) in feed samples were determined by Weende Analysis methods and crude fibre (CF) quantities by Crampton and Maynard's method. Acid detergent fibre (ADF) and acid detergent lignin (ADL) contents were determined by Van Soest analysis. The equations developed by $\mathrm{CF}, \mathrm{ADF}$ and $\mathrm{ADL}$ was used to calculate the ME values of feeds for ruminants. Dry matter values of the roughages varied between 90.12-95.31\%. mean CP and CF levels were found as 20.26, 12.11, 5.61, 3.63, 12.15\% and 24.71, 30.62, $33.30,45.53,33.52 \%$ for good quality alfalfa hay, low quality alfalfa hay, corn silage, wheat straw and grape pomace, respectively. In this study, the nutrient composition and energy values of some roughages produced in Kirikkale region were tabulated.

Key words: Metabolizable energy, nutrients, roughages.

\section{Giriş}

Hayvansal ürünlerin insan beslenmesindeki önemi tartışılmazdır. $\mathrm{Bu}$ nedenle hayvanların düzenli ve rasyonel bir şekilde beslenmeleri için, yemlerin yapısında bulunan besin maddelerinin ve enerji değerlerinin bilinmesi gereklidir. Hayvansal üretimin artması iki koşula bağlıdır. Bunlardan birincisi hayvanların genetik bakımından yüksek verim gücüne sahip olmaları, ikinci ve en önemli koşul ise verimlerine uygun bir şekilde hazırlanmış dengeli bir rasyon ile beslenmeleridir.

Hayvan beslemede konsantre ve kaba yemler olmak üzere başlıca iki yem kaynağı kullanılmaktadır. Bunlardan kaba yemler ucuz, ruminantların rumen mikroflorasında gerekli enzimlerin salgılanmasına yardımcı olması ve rumen gelişimini hılandırması bakımından önemli olup hayvanların yaşam ve verim payı ihtiyaçlarının ve hayvanlara vitamin ve mineral sağlamada önemlidir. Ayrıca ruminant rasyonlarında kaba yemlerin yeterli miktarlarda bulunmaması önemli metabolik ve sindirim bozukluklarına neden olmaktadır (11).

Hayvanların kaba yem ihtiyacının karşılandığı kaynaklar, doğal çayır ve meralar, yem bitkileri (yonca, korunga, fiğ, bakla, bezelye, sorgum, sudan otu ve hasıl mısır), harman kalıntıları (buğdaygil ve baklagil samanları, kavuzlar) ile yeşil ve su bakımından zengin (posa ve cibre) yemlerdir. Ülkemizde üretilen kaba yemler hayvanların ihtiyacını yeterince karşılayamamaktadır. Bu durumun nedenleri arasında doğal çayır-mera alanlarının yetersizliği, vejetasyon döneminin kısalığı, birim alandaki ot miktarının düşük ve yem bitkileri ekim alanlarının az olması da gösterilebilir (11). 
Kırıkkale'de 2004 yılı verilerine göre toplam tarım alanı 3.065.060 dekar olup, bunun 2.054.177 dekarı ekilen tarla alanı olarak kullanılmaktadır. Yem bitkileri tarımı 15.113 dekar alanda yapılmakta ve bu alandan 114 ton korunga, 2.625 ton yonca, 2.733 ton fiğ otu ve 5.811 ton silajlık misır üretilmektedir. Bağcılık 27.900 dekar alanda yapılmakta, bu alandan sofralık, kurutmalık ve şaraplık çeşitlerden oluşan 7.673 ton üzüm elde edilmekte ve bunun 3.208 tonunu $(\% 41.8)$ şaraplık üzümler oluşturmaktadır (4).

Türkiye'de yem hammaddelerinin bölgelere göre besin madde ve enerji içeriklerini gösteren standart tabloların olmaması, farklı bölgelerden sağlanan yem maddelerinin besin madde ve enerji içerikleri hakkında sağlıklı bilgi edinilmesini engellemektedir.

Bu çalışmada Kırıkkale'de üretilen ya da yetiştirilen ve ruminantların beslenmesinde yaygın olarak kullanılan bazı kaba yemlerde besin madde miktarları ve metabolize olabilir enerji içeriklerinin belirlenmesi amaçlanmıştır.

\section{Materyal ve Metot}

Araştırmada Kırıkkale yöresinde üretilen ve ruminantların beslenmesinde yaygın olarak kullanılan 16 adet yonca kuru otu, 6 adet macar fiği kuru otu, 6 adet misır silajı, 6 adet kuru mısır hasılı, 6 adet buğday saman1, 6 adet nohut samanı ve 6 adet üzüm cibresi olmak üzere toplam 52 adet kaba yem numunesi kullanılmıştır.

Besin madde ve enerji içerikleri belirlenecek olan üzüm cibresi Kalecik'te bulunan özel bir Şarap Fabrikasından 2004-2005 yillarının hasat mevsiminde kuru olarak temin edilmiştir. Özel hayvancılık işletmelerinden sağlanan diğer kaba yemler ise bu işletmelerin kendi ürettikleri ve 2005 yılına ait ürünlerden oluşmaktadır.. Toplanan kaba yemler öğütülerek analize hazırlanmıştır. Mısır silajı ham besin maddelerinin tayini için 60oC'de kurutulduktan sonra ögütülmüş ve analize hazır hale getirilmiştir. Yem maddelerinin kuru madde (KM), ham kül (HK), ham protein (HP) ve ham yağ (HY) düzeyleri Weende analiz sistemi (5)'ne göre, ham selüloz (HS) düzeyleri Crampton ve Maynard (6) metoduna göre, asit deterjan fiber (ADF) ve asit deterjan lignin (ADL) miktarları ise Van Soest (22) yöntemine göre belirlenmiştir. ME düzeyleri; MEHS, kcal/kg KM = 3309.5 - 35.64 x HS; MEADL, $\mathrm{kcal} / \mathrm{kg} \mathrm{KM}=2764-102.73 \mathrm{x}$ ADL; $\mathrm{MEADF}+\mathrm{HS}, \mathrm{kcal} / \mathrm{kg} \mathrm{KM}=3464.7-58.10 \times \mathrm{ADF}+$ 27.99 x HS; MEADF, MJ/kg KM $=14.70-0.150$ x ADF formülleri kullanılarak hesaplanmıştır $(13,14,15)$.

\section{Bulgular}

Kırıkkale yöresinde üretilen yonca kuru otu, macar fiği kuru otu, mısır silajı, kuru mısır hasılı, buğday samanı, nohut samanı ve üzüm cibresi gibi bazı kaba yemlerde KM, HP, HY, HS, HK, ADF ve ADL içerikleri Tablo 1'de ve bu kaba yemlerin farklı formüller ile hesaplanan ME düzeyleri ise Tablo 2'de gösterilmiştir

\section{Tartışma ve Sonuç}

Kirıkkale yöresinde üretilen ve ruminant beslemede yaygın olarak kullanılan bazı kaba yem maddelerinin besin madde içerikleri ile metabolize olabilir enerji düzeylerini belirlemek amacıyla yapılan bu çalışmada, yonca kuru otu, macar fiği kuru otu, mısır silajı, kuru mısır hasıll, buğday samanı, nohut samanı ve üzüm cibresi değerlendirmeye alınmıştır.

Çalışmada kullanılan kaba yem maddelerine ait besin madde içeriklerinin verildiği Tablo 1 incelendiğinde; yonca kuru otu, macar fiği kuru otu, kuru misır hasıl1, buğday samanı, nohut samanı ve üzüm cibresi gibi kaba yem maddelerinde kuru madde değerlerinin \%90' 1 n üzerinde olduğu (\%90.12-95.31) ve dolayısıyla iyi bir kurutma dönemi geçirdikleri belirlenmiştir. Kuru otlarda KM içeriklerinin genellikle \%88-92 arasında değişiklik gösterdiği bildirilmektedir $(10,18)$.

Kaba yemlerin ham protein düzeylerine bakıld1ğında KM bazında; yonca kuru otlarında \%11.44-20.79, misir silajinda \%5.08-6.33, kuru misir hasilinda \%3.004.47, üzüm cibresinde ise \%11.34-12.59 olarak belirlenmiştir. Bunlar literatür bildirişleri ile karşılaştırıldığında, yonca kuru otu için elde edilen bulgular, Kara ve Deniz (12)'in \%13.15, Abaş ve ark. (1)'nın \%18.42, Çerçi ve ark. (7)'nın \%19.97, Şeker (21)'in \%13.61, Denek ve Deniz (9)'in \%15.19, uluslararas1 referans kabul edilen tablolardaki $(8,17) \% 15-20$ ham protein olarak bildirdikleri bulgulara benzer bulunmuştur. Bazılarında iyi kaliteli, bazılarında ise kötü kaliteli yonca kullanıldığ1 görülmektedir. Alçiçek ve ark. (3) 16 farklı işletmeden alınan mısır silajı örneklerinde ham protein düzeylerini \%4.09-9.03 arasında, Denek ve Deniz (9) ise \%5.63 olarak saptamışlardır. Uluslararası referans kabul edilen tablolarda $(8,17)$ ise ortalama ham protein miktarları mısır hasılında \%3.2 ve üzüm cibresinde $\% 13$ olarak verilmiştir. Araştırmada elde edilen sonuçlara göre mısır silajı $(3,9)$ ve mısır hasılına $(8,17)$ ait sonuçların bu literatür bildirişleri ile uyum içerisinde olduğu, buna karşılık üzüm cibresine ait ham protein sonuçlarının literatür $(8,17)$ bildirişlerinden daha düşük, Sarıçiçek ve Kılıç (20)'ın sonuçları (\%11.54) ile uyumluluk gösterdiği belirlenmiştir. Kaba yemlerin ham protein miktarlarındaki farklılıklar, bitkilerin vejetasyon dönemi ve biçim zamanına bağlı olarak oluşmaktadır.

İncelenen kaba yem örneklerinde ham yağ düzeyleri KM bazında; yonca kuru otlarında \%1.04-2.62, misır silajında \%1.27-2.73 ve üzüm cibresinde \%7.25-8.14 
Tablo 1. Kaba yemlerin besin madde içerikleri, \% KM (ortalama, min-max)

Table 1. Nutrient contents of the roughages, $\%$ DM (mean, min-max)

\begin{tabular}{lccccccc}
\hline Yem maddeleri & KM & HP & HY & HS & HK & ADF & ADL \\
\hline Yonca kuru otu & 92.87 & 20.26 & 2.33 & 24.71 & 8.74 & 33.52 & 8.26 \\
(iyi kaliteli) (n=8) & $91.70-93.87$ & $19.68-20.79$ & $1.96-2.62$ & $23.37-26.56$ & $7.48-10.19$ & $31.97-34.15$ & $7.63-8.84$ \\
Yonca kuru otu & 91.79 & 12.11 & 1.47 & 30.62 & 10.57 & 39.64 & 9.92 \\
(kötü kaliteli) (n=8) & $90.12-93.51$ & $11.44-12.92$ & $1.04-2.50$ & $28.25-34.89$ & $9.91-11.27$ & $37.43-41.55$ & $8.57-11.58$ \\
Macar fiği kuru otu & 92.36 & 12.85 & 0.94 & 30.00 & 7.70 & 35.44 & 7.42 \\
(n=6) & $91.97-93.08$ & $11.08-13.83$ & $0.34-1.89$ & $29.37-30.69$ & $7.58-7.77$ & $35.14-35.92$ & $6.56-8.32$ \\
Misir silaj1 & 94.33 & 5.61 & 1.76 & 33.30 & 8.10 & 32.99 & 6.26 \\
(n=6) & $93.72-95.31$ & $5.08-6.33$ & $1.27-2.73$ & $29.41-37.02$ & $7.62-8.48$ & $31.64-35.10$ & $5.93-6.85$ \\
Kuru misır hasıl1 & 91.56 & 3.83 & 1.47 & 48.10 & 8.02 & 55.89 & 10.30 \\
(n=6) & $91.42-91.69$ & $3.00-4.47$ & $1.02-2.05$ & $46.89-49.06$ & $7.67-8.22$ & $53.84-59.20$ & $9.58-10.87$ \\
Buğday saman1 & 92.52 & 3.63 & 1.77 & 45.53 & 6.37 & 57.50 & 15.07 \\
(n=6) & $92.06-93.07$ & $3.43-3.78$ & $0.88-2.64$ & $44.75-46.01$ & $6.26-6.50$ & $57.17-57.67$ & $14.66-15.44$ \\
Nohut samanı & 92.79 & 5.89 & 1.35 & 31.92 & 7.48 & 42.80 & 9.31 \\
(n=6) & $92.14-93.92$ & $4.90-6.45$ & $0.86-2.24$ & $29.23-36.45$ & $5.93-8.56$ & $41.34-44.34$ & $7.92-10.74$ \\
Üzüm cibresi & 93.77 & 12.15 & 7.63 & 33.52 & 10.90 & 53.45 & 34.46 \\
$(\mathrm{n}=6)$ & $92.40-94.57$ & $11.34-12.59$ & $7.25-8.14$ & $33.06-34.28$ & $10.18-11.43$ & $52.26-55.78$ & $34.22-34.74$ \\
\hline & & & & & & &
\end{tabular}

Tablo 2. Kaba yemlerin HS, ADL ve ADF içeriklerinden yararlanılarak hesaplanan ME düzeyleri (MJ/kg KM)

Table 2. Calculated ME levels using HS, ADL and ADF contents of roughages (MJ/kg DM)

\begin{tabular}{|c|c|c|c|c|c|}
\hline \multirow[b]{2}{*}{ Yem maddeleri } & \multirow[b]{2}{*}{$\mathrm{n}$} & \multicolumn{4}{|c|}{$\mathrm{ME}(\mathrm{MJ} / \mathrm{kg} \mathrm{KM})$} \\
\hline & & $\mathrm{ME}_{\mathrm{HS}}$ & $\mathrm{ME}_{\mathrm{ADL}}$ & $\mathrm{ME}_{\mathrm{ADF}+\mathrm{HS}}$ & $\mathrm{ME}_{\mathrm{ADF}}$ \\
\hline $\begin{array}{l}\text { Yonca kuru otu } \\
\text { (iyi kaliteli) }\end{array}$ & 8 & $\begin{array}{c}11.22 \\
11.00-11.39\end{array}$ & $\begin{array}{c}8.89 \\
8.57-9.32\end{array}$ & $\begin{array}{c}10.35 \\
10.02-10.49\end{array}$ & $\begin{array}{c}10.80 \\
10.61-10.95\end{array}$ \\
\hline $\begin{array}{l}\text { Yonca kuru otu } \\
\text { (kötü kaliteli) }\end{array}$ & 8 & $\begin{array}{c}10.51 \\
10.15-10.79\end{array}$ & $\begin{array}{c}8.33 \\
7.66-8.87\end{array}$ & $\begin{array}{c}9.74 \\
8.96-10.49\end{array}$ & $\begin{array}{c}10.07 \\
9.73-10.34\end{array}$ \\
\hline Macar fiği kuru otu & 6 & $\begin{array}{c}10.51 \\
10.40-10.67\end{array}$ & $\begin{array}{c}9.33 \\
8.98-9.75\end{array}$ & $\begin{array}{c}10.58 \\
10.53-10.62\end{array}$ & $\begin{array}{c}10.60 \\
10.52-10.69\end{array}$ \\
\hline Misır silajı & 6 & $\begin{array}{c}8.87 \\
8.32-9.45\end{array}$ & $\begin{array}{c}8.87 \\
8.61-9.01\end{array}$ & $\begin{array}{c}10.37 \\
10.24-10.57\end{array}$ & $\begin{array}{c}9.75 \\
9.44-9.95\end{array}$ \\
\hline Kuru misir hasilı & 6 & $\begin{array}{c}7.94 \\
7.80-8.10\end{array}$ & $\begin{array}{c}8.20 \\
7.97-8.49\end{array}$ & $\begin{array}{c}7.87 \\
7.12-8.48\end{array}$ & $\begin{array}{c}7.67 \\
7.20-7.97\end{array}$ \\
\hline Buğday samanı & 6 & $\begin{array}{c}8.17 \\
8.04-8.30\end{array}$ & $\begin{array}{c}6.02 \\
5.79-6.25\end{array}$ & $\begin{array}{c}7.02 \\
6.92-7.11\end{array}$ & $\begin{array}{c}7.26 \\
7.15-7.33\end{array}$ \\
\hline Nohut samanı & 6 & $\begin{array}{c}10.15 \\
9.56-10.53\end{array}$ & $\begin{array}{c}8.46 \\
7.69-9.12\end{array}$ & $\begin{array}{c}8.95 \\
8.47-9.20\end{array}$ & $\begin{array}{c}9.42 \\
9.25-9.75\end{array}$ \\
\hline Üzüm cibresi & 6 & $\begin{array}{c}9.76 \\
9.52-10.03\end{array}$ & - & $\begin{array}{c}6.39 \\
5.78-6.85\end{array}$ & $\begin{array}{c}7.66 \\
7.18-8.06\end{array}$ \\
\hline
\end{tabular}

olarak belirlenmiştir. Yonca kuru otlarında ham yağ miktarlarını Şeker (21) \%1.48, Abaş ve ark. (1) \%2.34, Kara ve Deniz (12) \%1.75, uluslararas1 referans kabul edilen tablolarda $(8,17) \%$ 1.7-3.5 olarak bildirilmiş, üzüm cibresinde ise ortalama ham yă miktarları uluslararası referans kabul edilen tablolarda $(8,17) \% 7.9$, Roy ve Kattnig (19) tarafından \%7.6 olarak verilmiş olup araştırmada elde edilen sonuçların bu literatür bildirişleri ile uyum içerisinde olduğu görülmektedir. Mısır silajında ise ham yă̆ miktarı Alçiçek ve ark. (3)'nın sonuçlarından (\%1.70-3.74) düşük olarak bulunmuştur.
Mısır silajlarında ham yağ miktarları, koçanda dane mısırın bulunup bulunmamasına göre değişmektedir.

Yemlerin ham selüloz içerikleri bakımından kaba yem maddeleri arasında \%23.37-49.06 oranında geniş bir dağılımın olduğu görülmektedir. Bu oran KM bazında; yonca kuru otlarında \%23.37-34.89, misir silajında \%29.41-37.02, buğday samanında \%44.75-46.01 ve üzüm cibresinde \%33.06-34.28 olarak bulunmuştur. Bu bulgular literatür bildirişleri ile karşılaştırıldığında, yonca kuru otlarında ham selüloz miktarlarının, Abaş ve ark. (1)'nın \%21.75-43.21 olarak bildirdikleri bulgulara 
benzer, Kara ve Deniz (12)'in \%35.32 ve Şeker (21)'in $\% 37.83$ olarak bildirdikleri bulgulardan düşük bulunduğu gözlenmiş̧tir. Analize tabi tutulan mısır silajlarının ham selüloz miktarları Alçiçek ve ark. (2)'nın bulduğu miktarlara (\%30.87-31.72) ve uluslararası referans kabul edilen tablolardaki (17) değerlere (\%32.3) benzer bulunmuştur. Buğday samanlarında ham selüloz miktarlarının Şeker (21) ile Abaş ve ark. (1)'nın sonuçlarına benzer, Denek ve Deniz (9)'in sonuçlarından yüksek bulunduğu görülmüştür. Samanların ham selüloz miktarları, yazlık veya kışlık oluşlarına göre farklılıklar göstermektedir. Üzüm cibresinin ham selüloz miktarının ise Roy ve Kattnig (19) ve uluslararası referans kabul edilen tablolarda $(8,17)$ verilen değerler ile uyum içerisinde olduğu saptanmıştır.

Yemlerde Van Soest'e göre belirlenen ve kaba yemlerin sindirilebilirliğinin bir göstergesi olan asit deterjan fiber miktarları KM bazında; yonca kuru otlarında \%31.97-34.15, misir silajinda \%31.64-35.10, buğday samanında \%57.17-57.67 ve üzüm cibresinde \%52.26-55.78 olarak bulunmuştur. ADF bakımından incelenen yem maddelerinin uluslararası referans kabul edilen tablolarda (17) yonca kuru otlarının (\%28-37) sonuçları ile uyum içerisinde olduğu; buna karşı1lık buğday samanının (\%54) daha düşük, mısır silajının (\%30) ve üzüm cibresinin (\%31.9) ise daha yüksek bir asit deterjan fiber sonucuna sahip olduğu görülmüştür. Üzüm cibresinin ADF miktarın Roy ve Kattnig (19); $\% 54$ olarak bildirmiş olup, sonuçların bu literatür bildirişi ile uyum içerisinde olduğu görülmektedir.

Denemede kullanılan kaba yemlerin hayvanlar tarafindan sindirilmeyen lignin içeriklerini ifade eden asit deterjan lignin miktarlarının KM bazında; en düşük (\%6.26) mısır silajında ve en yüksek (\%34.46) üzüm cibresinde olduğu saptanmıştır. Asit deterjan lignin miktarları mısır silajında Alçiçek ve ark. (2)'nın sonuçlarından (\%3.88-5.10) yüksek, yonca kuru otunda ise Kara ve Deniz (12)'in bulduğu sonuçlardan (\%12.69) düşük bulunmuştur.

Çalışmada kullanılan kaba yem maddelerine ait metabolize olabilir enerji düzeyleri hücre duvarı unsurlarından ham selüloz, asit deterjan fiber ve asit deterjan lignin miktarları kullanılarak hesaplanmış ve Tablo 2'de verilmiştir. Mısır silajının metabolize olabilir enerji düzeylerinin hesaplanmasında HS içeriği kullanılarak elde edilen bulgular, Alçiçek ve ark. (2)'nın 9.12-9.25 MJ $/ \mathrm{kg} \mathrm{KM}$ olarak elde ettikleri bulgulara benzer bulunmuştur. Özkul ve ark. (16) metabolize olabilir enerji düzeylerini ADF miktarlarını kullanarak yaptıkları hesaplamalarda misır silaj1, yonca kuru otu ve buğday samanında sırasiyla $8.42-11.05,8.88-10.26$ ve 5.83-7.17 MJ/kg KM, ADL içeriğini kullanarak hesapladıklarında aynı yem maddelerinde sırasıyla 7.70-
$10.06,6.56-8.66$ ve $6.59-8.37 \mathrm{MJ} / \mathrm{kg} \mathrm{KM}$ olarak belirlemişlerdir. ADF ve ADL içerikleri ile hesaplanan yonca kuru otu ve misır silajına ait ME düzeylerinin bu literatür ile uyum içerisinde olduğu, buğday samanının ise bu literatürden daha düşük bir ME düzeyine sahip olduğu belirlenmiştir (16).

Kaba yemlerin besin madde içeriklerine, yem bitkisinin türü, gübreleme ve sulama, toprağın yapısı, iklim, hasat zamanı, kurutma ve depolama sirasındaki işlemler gibi pek çok faktör etki etmektedir.

Sonuç olarak, ruminantların beslenmesinde kullanılan kaba yemlerin hücre duvarı unsurlarının rutin bir şekilde belirlenerek yem tablolarına alınması ve yem enerji içeriğinin daha pratik, ekonomik ve kolay bir şekilde hesaplanması ülke hayvancılığına yarar sağlayacaktır. Ayrıca bu yönlü araştırmalar tekrarlanarak ve daha fazla sayıda yem maddesinde analizler yapılarak, Kırıkkale yöresinde üretilen kaba yem maddelerine ait tablolar oluşturulmalıdır.

\section{Kaynaklar}

1. Abaş I, Özpınar H, Kutay HC, Kahraman R, Eseceli H (2005): Determination of the metabolizable energy (ME) and net energy lactation (NEL) contents of some feeds in the Marmara region by in vitro gas technique. Turk J Vet Anim Sci, 29, 751-757.

2. Alçiçek A, Sevgican F, Şayan Y, Çapçı T, Özkul H (1997): Kaba yemlerde enerji içeriğinin hücre çeperi fraksiyonları ile saptanmasina yönelik bir araştırma. Ege Üniv Zir Fak Derg, 34, 41-48.

3. Alçiçek A, Tarhan F, Özkan K, Adışen F (1999): İzmir ili ve civarında bazı süt sı̆̆ırcıllı̆ işletmelerinde yapılan silo yemlerinin besin madde içeriği ve silaj kalitesinin saptanması üzerine bir araştırma. Hayvansal Üretim, 3940, 54-63.

4. Anonim (2004): 2004 yll il istatistik raporu. TC Tarım ve Köyişleri Bakanlığı Kırıkkale İl Müdürlüğü, Kırıkkale.

5. AOAC (1984): "Official Methods of Analysis". 14th Ed., Association of Official Agricultural Chemists, Washington. D.C.

6. Crampton EW, Maynard L (1983): The relation of cellulose and lignin content to nutritive value of animal feeds. J Nutr, 15, 383-395.

7. Çerçi İH, Seven PT, Azman MA, Birben N (2003): Ruminant yemlerinin farkl in vitro yöntemlerle metabolize olabilir enerjilerinin belirlenmesi. II. Ulusal Hayvan Besleme Kongresi, 18-20 Eylül, Konya, 419-423.

8. Dale N, Batal A (2005): 2005 Feedstuffs reference issue and buyers guide, 76, 16-22.

9. Denek N, Deniz S (2004): Ruminant beslemede yaygin olarak kullanılan kimi kaba yemlerin sindirilebilirlik ve metabolik enerji düzeylerinin in vitro yöntemlerle belirlenmesi. Turk J Vet Anim Sci, 28, 115-122.

10. Ensminger ME, Oldfield JE, Heinemann WW (1990): "Feeds and Nutrition". 2nd ed., The Ensminger Publishing Company. Clovis, California 
11. Ergün A, Tuncer ŞD, Çolpan İ, Yalçın S, Yıldız G, Küçükersan MK, Küçükersan S, Şehu A (2002): "Yemler Yem Hijyeni ve Teknolojisi" Ankara Üniversitesi Vet Fak Hayvan Besleme ve Beslenme Hastalıkları Anabilim Dalı, Ankara.

12. Kara MA, Deniz S (2005): Van yöresinde üretilen kuru otların besin madde içeriği ile sindirilebilirlik ve enerji içeriklerinin in vitro ve in sacco yöntemlerle belirlenmesi. III. Ulusal Hayvan Besleme Kongresi, 7-10 Eylül, Adana, 505-511.

13. Kirchgessner M, Kellner RJ (1977): Zur schatzung der umsetzbaren energie von grün- und rauhfutter mit einfachen kenndaten. Tierph Tierernahrung Futter, 38, 297-301.

14. Kirchgessner M, Kellner RJ (1981): Schatzung des energetischen futterwertes von grün- und rauhfutter durch die cellulasemethode. Landwirtsch. Forsch, 34, 276-281.

15. Kirchgessner M, Kellner RJ, Roth FX, Ranfft K (1977): Zur Schatzung des Futterwertes mittels Rohfaser und der Zellwandfraktionen der Detergentien-Analyse. Landwirtsch. Forsch, 30, 245-250.

16. Özkul H, Şayan Y, Polat M, Çapçı T (2005): Comparison of metabolizable energy values of roughages determined by regression equations using in vivo and invitro parameters. Pak J Biol Sci, 8, 696-700.
17. Perry TW, Cullison AE, Lowrey RS (2004): "Feeds and Feeding”. 6th ed., Prentice Hall, New Jersey, USA.

18. Pond WG, Church DC, Pond KR (1995): "Basic Animal Nutrition and Feeding”. 5th ed., John Wiley \& Sons Inc, Hoboken, NJ.

19. Roy, KH , Kattnig, RM (2000): Value and quality assurance of by product feeds. In: Beef Cattle Handbook. University of Wisconsin, Extension, Coop., BCH-5056.

20. Sarıçiçek BZ, Kılıç Ü (2002): Üzüm cibresinin yem değerinin belirlenmesi üzerine bir araştırma. OMÜ Zir Fak Derg, 17, 9-12.

21. Şeker E (2002): The determination of the energy values of some ruminant feeds by using digestibility trial and gas test. Revue Med Vet, 153, 323-328.

22. Van Soest PJ (1963): Use of detergent in the analysis of fibrous feed. I: A rapid method for the determination of fiber and lignin. J Ass Off Agric Chem, 46, 825-835.

Geliş tarihi: 25.12.2006 / Kabul tarihi: 12.07.2007

\section{Yazışma adresi}

Doç. Dr. Tülin Güngör

Kırıkkale Üniversitesi

Veteriner Fakültesi

Kampüs, 71451, Yahşihan/Kırıkkale

e-mail: tulingungor@kku.edu.tr 